\title{
Competência para a prestação de serviços públicos e o transporte coletivo rodoviário no meio ambiente urbano
}

\section{Emerson Gabardo}

Doutor em Direito do Estado pela UFPR. Professor de Direito Administrativo da Graduação e do Mestrado da UniBrasil. Diretor-Geral do Instituto de Direito Romeu Felipe Bacellar. Advogado do escritório Guilherme Gonçalves e Advogados Associados.

\begin{abstract}
Resumo: $\mathrm{O}$ artigo trata dos serviços públicos de transporte coletivo rodoviário no Brasil. Inicia descrevendo o regime geral dos serviços públicos como uma espécie de atividade econômica em sentido amplo. Aborda tal regime jurídico a partir da idéia constitucional de um modelo de Estado social e interventor. Trata da organização constitucional de competências para a prestação de serviços públicos focando a questão da localização federativa e da regionalização urbana. Destaca o caráter essencial dos serviços públicos de transporte coletivo de passageiros. Finaliza ressaltando a relação entre os serviços públicos de transporte coletivo rodoviário e a questão do meio ambiente urbano.
\end{abstract}

Palavras-chave: Serviço público. Transporte coletivo. Meio ambiente.

Sumário: 1 Os serviços públicos como atividade econômica - 2 O regime jurídico dos serviços públicos num Estado social-interventor - 3 A organização constitucional de competências para a prestação de serviços públicos entre localização e regionalização urbana - 4 O caráter essencial dos serviços públicos de transporte coletivo de passageiros - $\mathbf{5}$ Os serviços públicos de transporte coletivo rodoviário em face do meio ambiente urbano Referências

\section{Os serviços públicos como atividade econômica}

Há muitas discussões teóricas a respeito do serviço público, seu conceito e seu regime jurídico. ${ }^{1} \mathrm{E}$ isso é natural quando em foco a alta carga de interdisciplinaridade incidente sobre a matéria. Além de ser sempre o resultado de uma escolha de caráter político, a tratativa dos serviços públicos exige um recuo às relações entre Direito e economia, ainda que se reconheça que tais pontos de vista contrastam quanto aos seus critérios ontológicos (autoridade/resultado). ${ }^{2}$ Independente de se entender o Direito e a economia como sistemas autônomos ou como parte de um

\footnotetext{
A construção teórica a respeito do serviço público e da atividade econômica ora colacionada foi extraída do texto sobre a matéria publicado no livro do autor intitulado Interesse público e subsidiariedade, no tópico 3 (Os serviços públicos e os serviços sociais como atividades econômicas) do Capítulo III (Os processos atuais de descentralização no Brasil e seus pontos frágeis) (cf.: GABARDO. Interesse público e subsidiariedade: o Estado e a sociedade civil para além do bem e do mal).

2 OLIVEIRA. Parceria público-privada: aspectos de direito público econômico, p. 28.
} 
mesmo campo de estudo, ${ }^{3}$ é fato inconteste que desde a constituição de sua soberania o Estado moderno se interessou pela atividade econômica. Dos tradicionais interesses fiscais, militares, políticos e de polícia chegando até a avançada proposta de responsabilização pelo desenvolvimento, os fins do Estado sempre estiveram ligados direta ou indiretamente à consecução de bens econômicos.

Atualmente, ou seja, na última década do século XX e nesta primeira do século XXI, o assunto privatização da economia recebeu um destaque sem precedentes. E um dos pontos-chave das discussões girava em torno da concessão de serviços públicos aos particulares. ${ }^{4}$ Não foram incomuns as assertivas de que o serviço público estava em uma "crise" de reconfiguração conceitual, perdendo suas características essenciais. Todavia, mais apropriadas parecem ter sido as reflexões que destacavam apenas a reversão de movimento de um pêndulo histórico, ${ }^{5}$ a partir do retorno a uma opção política descentralizante, em detrimento das políticas públicas predominantes a partir do Estado de bem-estar consolidado no período do pósguerra (ainda que esta consolidação tenha sido parcial em alguns Estados, tardia em outros e meramente simbólica nos Estados não-desenvolvidos como o Brasil). ${ }^{6}$ A idéia de crise, portanto, não é tão nova e tende a retornar sempre que ocorre alguma alteração de paradigma estatal interventivo. ${ }^{7}$

Outro ponto importante e por vezes esquecido é que a Constituição Federal de 1988, ainda que fortemente inspirada em um momento histórico antecedente, mediante a consagração no plano do "dever ser" de um autêntico e fortemente estabelecido "Estado de bem-estar social”, já previa, como elemento típico deste regime interventor, a competência para os entes políticos promoverem a delegação dos serviços públicos privativos do Estado. Não é possível entender, portanto, a delegação de serviços públicos aos particulares como um movimento apenas inerente ao predomínio ideológico do neoliberalismo típico da década de 1990. Na história do Estado moderno ocidental, a variação de competência entre a prestação privada e

\footnotetext{
NUSDEO. Curso de economia: introdução ao direito econômico, p. 19 et seq.

4 Sobre o assunto deve-se ressaltar a excelente e completa obra de Marcos Juruena (Cf.: SOUTO. Desestatização: privatização, concessões, terceirizações e regulação. 4. ed.).

5 TÁCITO. O retorno do pêndulo: serviço público e empresa privada: o exemplo brasileiro. In: Temas de Direito Público: estudos e pareceres, p. 721 et seq.

6 GABARDO. Eficiência e legitimidade do Estado, p. 104 et seq.

Interessante a observação histórica de Odete Medauar de que na década de 1950 foi publicado um livro intitulado "Crise da noção de serviço público", de Jean-Louis Corail (Cf.: MEDAUAR. Ainda existe serviço público? In: TÔRRES (Coord.). Serviços públicos e direito tributário, p. 32).
} 
prestação pública de serviços é condicionada muito menos por mudanças de caráter legislativo do que por alterações de costumes, de políticas públicas e, fundamentalmente, de realinhamentos da ordem econômica. Isso não significa que é menos relevante o condicionamento previsto no ordenamento positivo sobre a matéria. Não parecem existir dois Estados cujos regimes jurídicos de prestação dos serviços públicos e/ou de exploração direta de atividade econômica em sentido estrito sejam exatamente os mesmos. Cada nação possui um passado que influencia suas opções políticas específicas, dentro da conjuntura temporal global (que em menor ou maior grau jamais deixou de influenciar as opções internas de cada país).

No caso brasileiro, a Constituição Federal de 1988 retratou de forma extensa e intensa opções políticas e jurídicas que, influenciadas pela ordem externa, definiram-se a partir de heterogêneos elementos nacionais, lobbies, grupos de pressão e as mais diversas forças e movimentos advindos de todos os setores da sociedade civil. Talvez seja este o motivo pelo qual, por vezes, parece ser um documento sobremaneira contraditório e complexo de ser interpretado. Particularmente com relação à temática da intervenção direta do Estado na economia, embora receba variação entre os diversos intérpretes legitimados, a atuação do Estado na esfera econômica no Brasil pode ser classificada em três espécies fundamentais: a) a política econômica; b) a intervenção; e c) a regulação. A política econômica equivale ao planejamento (artigo 174 da CF/88) e pode ser realizada mediante normas configuradoras de instrumentos diretos de controle (fixação de salários, racionamento, tabelamento de preços) e diretos de adaptação institucional (legislação de efeitos concretos, criação de órgãos), além dos indiretos (de finanças, monetários, creditícios, cambiais). A intervenção pode ocorrer de duas formas principais: por absorção, quando o Estado assume integralmente a atividade econômica (caso do monopólio de atividade econômica fundamentado no artigo 173 ou do privilégio de serviço público fundado no artigo 175 da CF/88); ou por participação, em que o Estado exerce a atividade simultaneamente aos particulares. ${ }^{8}$ Como visto, seja num ou noutro caso, as duas formas principais de intervenção direta do Estado na economia são justamente a atividade econômica em sentido estrito e o serviço público. A regulação (também reconhecida no artigo 174 da CF/88)

\footnotetext{
8 Esta classificação foi montada a partir da conjugação da doutrina de Fábio Nusdeo e Eros Roberto Grau (embora não coincida exatamente com nenhuma das duas) (Cf.: NUSDEO. Curso de economia ..., op. cit., p. 215 et seq. e GRAU. A ordem econômica na Constituição de 1988, op. cit., p. 138 et seq.).
} 
manifesta-se por intermédio de ações de controle normativo e fiscalizatório seja por direção (estabelecimento de um comportamento compulsório), seja por indução (mera provocação, fomento). ${ }^{9}$

Fala-se em atividade econômica em "sentido estrito", pois o serviço público também possui a ontologia de uma atividade econômica, apesar do sistema constitucional não reconhecer tal nomenclatura. Na realidade, a questão resolve-se satisfatoriamente (e de forma plenamente compatível com a Constituição) quando estudado o próprio conceito de atividade econômica: a ação de escolha e busca de recursos (bens) para o atendimento das necessidades econômicas. Será econômica toda atividade que tenha por objeto um bem econômico. Uma interessante definição dos bens econômicos é aquela que os entende como aqueles "objetos relativamente escassos, suscetíveis de posse e que servem, direta ou indiretamente, para a satisfação das necessidades humanas". ${ }^{10}$ A doutrina em geral define-os como aqueles recursos úteis e escassos. ${ }^{11}$ Tais conceitos devem ser entendidos no seu peculiar sentido, mediante uma ligação direta com a idéia de necessidade humana. Dessa forma, tem-se que todo bem inútil não é escasso e todo bem abundante é inútil. O conceito de necessidade é polêmico. Sem embargo, é pertinente o sentido que lhe dá Alberto Baltra Cortes quando afirma que se trata de um fator eminentemente psicológico composto por três elementos: a) presença de uma sensação penosa e desagradável; b) conhecimento do meio para eliminar a sensação desagradável; e c) vontade de adquirir o meio (mediante a ponderação entre a satisfação a ser obtida e o sacrifício para alcançá-la). Porém, é preciso ressaltar que nem todas as necessidades são econômicas. Somente assim serão entendidas aquelas que puderem ser satisfeitas por bens econômicos. ${ }^{12}$ E os bens econômicos, como já asseverado, serão justamente aqueles que se caracterizem pela sua utilidade (no sentido específico da capacidade de satisfação de uma necessidade humana — ou seja, sua "ofelimidade"), escassez (não podem ser encontrado livremente na natureza) e, também, capacidade de poderem ser valorados e transmitidos. Todos estes elementos estão imbricados. ${ }^{13}$

\footnotetext{
9 Sobre o conceito e as características da regulação ver: JUSTEN FILHO. O direito das agências reguladoras independentes.

10 GASTALDI. Elementos de economia política. 17. ed., p. 88.

11 NUSDEO. Curso de economia ..., op. cit., p. 34.

12 CORTES. Teoria económica, p. 31 et seq.

13 NUSDEO. Curso de economia ..., op. cit., p. 34; e GASTALDI. Elementos de economia política, op. cit., p. 88 et seq.
} 
Recorrendo-se a estas considerações conceituais preliminares, pode-se chegar à conclusão de que a classificação de Eros Roberto Grau, que arrola a atividade em sentido estrito e o serviço público como espécies da atividade econômica em sentido amplo, parece absolutamente consonante não só com a Constituição, mas com a própria natureza da expressão. O gênero se constitui pelo fato de caracterizar-se fundamentalmente pelo fornecimento de um bem econômico à coletividade. ${ }^{14}$ As espécies se diferenciam tanto pela materialidade de sua condição quanto pelo regime jurídico a elas incidente. Entretanto, este enquadramento normativo não é pacífico. Romeu Felipe Bacellar Filho, partindo da interpretação constitucional de seus dispositivos expressos, não encontra esta diferenciação entre atividade em sentido estrito e em sentido amplo, preferindo diferenciar ontologicamente o serviço público da atividade econômica; ademais, propõe a alteração da própria natureza da atividade econômica quando prestada pelo Estado (mediante o reconhecimento de um regime jurídico diferenciado dos particulares e próximo ao das atividades eminentemente administrativas). ${ }^{15}$

A atividade econômica em sentido estrito retrata atividade que não é considerada pelo ordenamento positivo de "relevância social peculiar", ou seja, não está enquadrada no critério de essencialidade. Ocorre que esta característica não lhe é peremptória, pois o sistema jurídico brasileiro admite a possibilidade da existência de atividades econômicas materialmente essenciais (reconhecidas pelo Direito ou não). Trata-se de uma excepcionalidade que em nada prejudica o estabelecimento do critério geral (que é a ausência de essencialidade). É o caso das atividades essenciais declaradas por lei como tal (ou simplesmente reconhecidas pela coletividade como de importância ímpar), mas que não receberam a publicatio, ou seja, não tiveram sua responsabilidade atribuída para o poder público. ${ }^{16}$

A atividade econômica em sentido estrito é uma ação típica dos particulares no Brasil, como uma decorrência natural do princípio da livre iniciativa. Para além de um direito de natureza negativa perante o Estado, ou seja, uma garantia contra a intervenção do poder, a Carta Magna estabelece uma garantia positiva, ao reservar com exclusividade a atividade econômica em sentido estrito aos agentes privados, conforme previsão do

\footnotetext{
${ }^{4}$ GRAU. A ordem econômica ..., op. cit., p. 141.

5 BACELLAR FILHO. Direito administrativo. 4. ed., p. 172 et seq. e 197 et seq.

16 GROTTI. O serviço público e a Constituição de 1988, p. 25.
} 
seu artigo 173, caput. Este dispositivo proíbe a exploração direta de atividade econômica pelo Estado, exceto nos casos que estejam ou que venham a ser previstos na Constituição, nos casos de segurança nacional (assim declarados pela União Federal) e nos casos em que estiver presente o relevante interesse coletivo estabelecido por lei. Se o Estado identificar qualquer destes casos, deverá propor a criação de pessoas jurídicas de direito privado (empresas públicas ou de sociedades de economia mista), que em regime de descentralização administrativa integrarão a vulgarmente chamada Administração indireta para que explorem a atividade mediante um regime jurídico misto (privado, porém parcialmente derrogado pelo Direito público). Por uma questão mais lógica que jurídica, o Estado somente poderá explorar atividade econômica em sentido estrito de forma organicamente direta (ainda que por entes da Administração indireta, conforme a terminologia adotada pelo Decreto-Lei no 200/67).

\section{O regime jurídico dos serviços públicos num Estado social- interventor}

Diferente do regime de exploração da atividade econômica em sentido estrito, o caso dos serviços públicos implica o reconhecimento de um regime muito mais complexo. ${ }^{17}$ Trata-se de uma importante noção histórica ligada ao Estado e, assim sendo, retrata um instituto dinâmico por essência. Sua definição popular raramente coincide com o entendimento que o pensamento oficial tem dele. E, ainda, é comum que o próprio posicionamento doutrinário a respeito do seu conceito retrate variações quando não fortes divergências, considerando que os sistemas jurídicos nem sempre trazem elementos suficientes para um fechamento conceitual. Ademais, como já asseverado, a idéia que se tem da própria ontologia dos serviços públicos varia conforme o modelo de Estado instituído pelo ordenamento jurídico-político, além do que, depende dos diferentes critérios distintivos, ainda que existam "aspectos consolidados" da sua noção, como aponta Monica Spezia Justen. ${ }^{18}$

De pronto, é preciso reafirmar que o serviço público nada mais é do que uma atividade econômica em sentido estrito que teve seu regime jurídico

\footnotetext{
17 Sobre a complexidade da conceituação de serviço público e as diferentes possibilidades de seu entendimento, ver: VALLE. O novo conceito de serviço público. In: GUIMARÃES (Coord.). Cenários do direito administrativo: estudos em homenagem ao professor Romeu Felipe Bacellar Filho, p. 511-552.

18 JUSTEN. A noção de serviço público no direito europeu, p. 59 et seq.
} 
alterado, mediante uma ação imperativa do Estado ao torná-lo típico. Como uma atividade econômica qualquer, submetia-se ao regime jurídico de Direito privado, caracterizado pela autonomia da vontade, capacidade universal, vinculação negativa ao Direito, disponibilidade de direitos e interesses e igualdade das partes. Diferentemente, como serviço público propriamente dito, será conduzido pelo regime jurídico de Direito público, cujos adjetivos fundamentais são mutatis mutandi, a heteronomia, a capacidade por atribuição legal, a vinculação positiva ao Direito, a indisponibilidade de direitos e interesses e a desigualdade entre as partes. ${ }^{19}$

É realmente paradoxal imaginar a prestação de um serviço público no regime jurídico de Direito privado. Ocorre que, por intermédio do processo de reformas gerenciais da década de 1990, romperam-se os limites estabelecidos originalmente entre o público e o privado, tornando-se comum a promoção de alternativas jurídicas até então inexistentes, e em relação às quais parte dos juristas apresentou fortes resistências. ${ }^{20}$ Vê-se que a questão é polêmica e, no mínimo, justifica o seguinte questionamento: se for possível prestar serviço público sob o regime privado, então cabe sustentar que o regime de Direito público (sentido formal) ainda é apto a caracterizálo? Não seria mais razoável supor que não se está mais diante de um serviço público? Caso se mantenha o entendimento de que a atividade é realmente serviço público, não seria inconstitucional (e logicamente incongruente) aplicar a ele um regime de Direito privado? Ainda, se o regime for desimportante para a caracterização ou não de um serviço público, então não seria o caso de assumir o critério material como exclusivo, abandonandose a tese de um "regime geral" e reconhecendo-se a setorialização como característica da ontologia dos serviços públicos no Brasil? ${ }^{21}$

Uma resposta interessante é aquela desenvolvida por João Batista Gomes Moreira, ao propor o abandono da dicotomia de regimes mediante o reconhecimento de que o Direito administrativo não seria público nem privado, situando-se fora das antigas categorias para prestigiar a

\footnotetext{
19 PAREJO ALFONSO. Eficacia y administración: três estúdios, p. 117.

${ }^{20}$ Como é o caso de Weida Zancaner. Cf.: ZANCANER. Limites e confrontações entre o público e o privado. In: BACELLAR FILHO (Coord.). Direito administrativo contemporâneo, p. 339-346. E também: BACELLAR FILHO. O poder normativo dos entes reguladores e a participação dos cidadãos nesta atividade. Serviços públicos e direitos fundamentais: os desafios da regulação na experiência brasileira. AeDP - Actualidad em el Derecho Público, n. 18/20, p. 68.

${ }^{21}$ Estas perguntas bem como a tratativa do assunto que envolve a questão foi extraída do texto sobre a matéria publicado no livro do autor intitulado "Interesse Público e Subsidiariedade", no tópico 3 (Os serviços públicos e os serviços sociais como atividades econômicas) do Capítulo III (Os processos atuais de descentralização no Brasil e seus pontos frágeis) (cf.: GABARDO. Interesse público e subsidiariedade ..., op. cit.).
} 
alocação da noção de "finalidade pública administrativa" no seu "centro de gravitação". ${ }^{22}$ Trata-se de uma idéia ousada e talvez inapropriada para a realidade brasileira, mas não deixa de indicar uma reflexão necessária.

No caso das atividades econômicas privadas exploradas pelo Estado, parece fácil a atribuição genérica e abstrata de uma predominância do regime privado parcialmente derrogado pelo Direito público, afinal, a situação não requer a existência de um regime especial que caracterize a atividade. A atividade já será privada, independentemente de uma especial recorrência ao Direito. Além do que, sua exploração pelo Estado é definida, constitucionalmente, a partir de critérios de natureza material (relevante interesse coletivo ou segurança nacional). O mesmo não ocorre com os serviços públicos, que não possuem esta delimitação em sede constitucional. Todos estes elementos dificultam sobremaneira a proposição de uma resposta definitiva sobre os questionamentos incidentes.

Mas o fato é que não basta o exercício da publicatio para que uma atividade econômica em sentido estrito transforme-se em serviço público. Os elementos políticos, sociológicos e filosóficos que se traduzem em determinada história da utilização de institutos como o serviço público são relevantes para a sua própria definição. São fatores que delineiam, a partir da mentalidade vigente, o caráter material imprescindível para a legitimação de qualquer tentativa formal de reconhecimento de um serviço como público. Os modelos de delegação dependem de várias questões e não somente de uma questão jurídica (reduzida à discricionariedade estatal). Embora seja essencial o reconhecimento do legislador, "somente é válido transformar em serviço público uma atividade que preencha certos requisitos”. Nestes termos, como bem ressalta Marçal Justen Filho, “o núcleo dos serviços públicos reside no aspecto material". ${ }^{23}$ Ademais, conforme continua o autor, nem todo o elenco constitucional de serviços públicos (como aqueles atribuídos à União Federal) consistem, obrigatoriamente e em qualquer caso, serviço público. Isso ocorre porque podem existir exemplos de alguns serviços especificamente considerados que, ao não se vincularem axiologicamente às finalidades essenciais ou à dignidade, restringem-se à natureza de atividade econômica em sentido estrito. Por exemplo, parece restar pacífico que nem todas as atividades de radiodifusão são serviço público. E vai mais longe ainda o autor, ao afirmar que a expressão

\footnotetext{
22 MOREIRA. Direito administrativo: da rigidez autoritária à flexibilidade democrática, p. 168.

23 JUSTEN FILHO. Teoria geral das concessões de serviço público, p. 15, 21.
} 
“autorização" prevista no artigo 21 da Constituição é incompatível com a existência de serviço público. ${ }^{24}$

Busca-se evitar, com o reconhecimento destes limites ao legislador, o entendimento de parte da tradicional doutrina de que "tudo seria serviço público em potencial”. Não é. ${ }^{25}$ Ou seja, excluídos dois campos: o que é serviço público obrigatoriamente e o que obrigatoriamente não é, o legislador infraconstitucional pode determinar outras atividades como serviço público (sendo, porém, tal atividade sujeita a limitações materiais e requisitos positivos extraídos do ordenamento). Assim, não seria possível, portanto, "transformar em serviço público uma atividade consistente, por exemplo, na fabricação de cachimbos ou de perucas". ${ }^{26}$

De fato, não há um regime jurídico extenso e bem estabelecido dos serviços públicos previsto expressamente na Constituição Federal. O artigo 175 assevera somente que serão prestados pelo Estado direta ou indiretamente (neste último caso, mediante o respeito ao regime licitatório). Decorrência inafastável desta disposição é a exclusão do serviço público da garantia inerente à livre iniciativa. Os particulares, a contrário senso, estão proibidos de prestar atividade que teve seu regime publicizado pela Constituição ou pela lei. Todavia, caso o Estado tome a decisão política de novamente repassá-lo aos particulares, poderá fazê-lo mediante a utilização do instituto da delegação. As concessões e as permissões de serviço público implicam o repasse da gestão ou execução do serviço (precedido ou não de obra pública). A primeira ocorre mediante contrato, cujo caráter é bilateral e o regime é especial, ainda que o contrato seja uma categoria que não pertença nem ao Direito público nem ao Direito privado, como propõe Romeu F. Bacellar Filho. A segunda consiste em um ato administrativo, embora seja cada vez mais discutível a sua natureza (que irá depender do caso concreto e das cláusulas regentes da relação). ${ }^{27}$

Se não entender necessária a delegação, deve o Estado prestar o serviço diretamente, criando para tanto as propaladas empresas públicas e sociedades de economia mista, que atuarão em um regime misto público, porém parcialmente derrogado pelo Direito privado (pois suas

\footnotetext{
24 JUSTEN FILHO. Teoria geral das concessões ..., op. cit., p. 44 et seq.

${ }^{25}$ Nesse sentido, vale a pena consultar a obra de Cesar A. Guimarães Pereira sobre o assunto: PEREIRA. Usuários de serviços públicos: usuários, consumidores e os aspectos econômicos dos serviços públicos, p. 263 et seq.

${ }^{26}$ JUSTEN FILHO. Teoria geral das concessões ..., op. cit., p. 48, 21.

27 BACELLAR FILHO. As concessões, permissões e autorizações de serviço público. In: CARDOSO (Org.). Curso de direito administrativo econômico, p. 408 et seq.
} 
personalidades serão de Direito privado). Obviamente, a opção por uma ou outra forma de descentralização produz conseqüências no plano normativo.

Contudo, não termina aqui a questão dos serviços públicos. Há situações em que determinadas atividades econômicas em sentido estrito serão declaradas como de titularidade estatal (como um dever público típico), mas não receberão a publicatio, ou seja, não serão excluídas da incidência do princípio da livre iniciativa. Trata-se de uma forte exceção, que pode ser interpretada de duas formas. Na primeira, adotada por Carlos Ari Sundfeld, em tal situação não se estará diante de um serviço público propriamente dito, mas do que pode ser denominado de um "serviço social" (terceira modalidade que não se confundiria com a atividade econômica em sentido estrito nem com o serviço público). Isso porque seu status constitucional não é enquadrável no artigo 173 nem no caput do artigo $175 .{ }^{28}$

Entretanto, há a segunda interpretação, desenvolvida por Eros Roberto Grau. Como materialmente é uma atividade essencial que, inclusive, foi juridicamente reconhecida como um dever típico do Estado (portanto de sua titularidade) seu enquadramento é realizado como sendo um efetivo serviço público, só que não privativo do Estado, pois poderá ser prestado livremente pelos particulares no regime jurídico de Direito privado (ainda que parcialmente derrogado pelo Direito público). ${ }^{29}$ Não se trata aqui, obviamente, de nenhum tipo de delegação. E nem o será quando o Estado resolver prestar, ele mesmo, o serviço. Neste caso cabem duas alternativas, que não são escolhidas discricionariamente, mas dependem da peculiaridade do caso. Em regra o ente estatal deverá descentralizar a atividade a uma autarquia ou fundação pública. Esta talvez seja a única exceção à regra de vedação à exploração de atividade econômica pelas pessoas jurídicas de Direito público (o que é plenamente justificável), pelo que, o regime de prestação será igualmente público. Excepcionalmente, vem-se difundindo a ampliação da possibilidade de prestação do serviço público não privativo do Estado mediante a simples firmação de convênio, consórcio, contrato de gestão ou termo de parceria. Institutos que fazem as vezes da delegação, ainda que com ela não se confundam, pois implicam apenas o estabelecimento contratual de uma parceria, considerando que a atividade é livre e, portanto, seria incongruente pensar em atribuir ao particular uma

\footnotetext{
28 SUNDFELD. Fundamentos de direito público, op. cit., p. 83.

${ }^{29}$ GRAU. A ordem econômica ..., op. cit., p. 153.
} 
prerrogativa que já lhe é própria. ${ }^{30} \mathrm{O}$ que não impede que, comumente, os governos acabem por promover, na prática, tal impropriedade jurídica.

É importante destacar que há uma distinção teleológica no tocante à intenção do prestador privado do serviço vinculado ao Estado. No caso dos serviços públicos privativos do Estado, há uma pretensão de lucro por parte do chamado "colaborador" que, na realidade, não tem intenção nenhuma de colaborar, mas de obter o maior núcleo de vantagens econômicas possível. No caso dos serviços públicos não privativos do Estado, em tese, a solução não pode ser a mesma, pois os agentes devem ter a intenção de colaborar, sem a preocupação com a obtenção de lucros. Afinal, se o objetivo for a obtenção de lucros, o agente privado pode se dedicar a esta atividade livremente, sem a necessidade de uma vinculação formal com o ente público.

Saliente-se que o repasse dos serviços públicos não privativos do Estado para o mercado ou para o terceiro setor exige como contrapartida uma ampliação da atuação do Estado na área da regulação e da fiscalização. Esta advertência é importante em face de algumas posições radicais como a de Luis Cabral de Moncada quando assevera que na área de serviços públicos como a saúde, com a privatização e a concorrência entre o setor público e o setor privado não poderá nem mesmo o Estado atuar como regulador, sob pena de uma "grosseira distorção da concorrência”. Sugere o autor que o controle adequado deve ser realizado por uma "entidade reguladora independente do Estado". ${ }^{31}$

No Brasil tais entidades reguladoras independentes do Estado não existem, pois no máximo há alguns entes análogos criados no bojo do projeto de reforma do Estado da década de 1990, mas que, na realidade, nada mais são do que autarquias especiais. Talvez o autor quisesse se referir às agências norte-americanas, cujo grau de autonomia é realmente grande. De qualquer modo, seu entendimento não é apropriado seja para o ordenamento português seja para o brasileiro (pois no tocante ao modelo de Estado interventor os dois sistemas constitucionais são parecidos). O fato é que mesmo as entidades independentes, sejam as agências americanas, sejam as autoridades européias, não são externas ao Estado, apenas compondo um local especial na estrutura administrativa. ${ }^{32} \mathrm{E}$ parece ser bastante

\footnotetext{
30 Sobre o assunto ver: OLIVEIRA. Contrato de gestão.

31 MONCADA. A subsidiariedade nas relações do Estado com a economia e a revisão constitucional. In: MIRANDA (Coord.). Estudos em homenagem ao prof. Doutor Joaquim Moreira da Silva Cunha, p. 51.

32 JUSTEN FILHO. O direito das agências ..., op. cit., p. 51.
} 
adequado que assim seja, pois a proposição de que a atuação como agente econômico conduziria à necessidade de abstenção de sua atuação como regulador não merece crédito nem mesmo no caso de exploração de atividade econômica em sentido estrito, que se dirá então na realização de atividades que lhe são típicas, tais como os serviços públicos não privativos do Estado. Não há que se contrapor, como faz o autor, duas formas de atuação estatais diferentes (a sempre necessária regulação e às vezes opcional intervenção). Tais atividades não se misturam nem se atrapalham se realizadas nos contornos constitucionais.

Reitere-se, ainda, que em face do dever administrativo previsto no artigo 175, inciso IV, da Constituição Federal, a doutrina administrativista brasileira chega a identificar um verdadeiro "direito fundamental ao serviço público adequado". ${ }^{33}$ Talvez esta conclusão possa ser entendida como exagerada, pois embora a prestação do serviço público seja um dever constitucional inerente ao próprio modelo de Estado, sua realização possui caráter eminentemente instrumental, visando garantir o rol de direitos fundamentais previstos na Constituição, estes sim, cujo caráter é material e finalístico. De qualquer modo, a importância da prestação de um serviço público adequado não pode ser diminuída, ainda que não seja reconhecido o seu caráter de fundamentalidade. E isso ocorre devido à sua vinculação material aos direitos humanos. Nesse sentido, a noção de serviço público é progressiva e histórica, sendo imperioso seu caráter mutável para que disponha de instrumentos tanto de eficiência operativa (consecução de um bom planejamento e uma boa formulação de metas) quanto adaptativa (adequada capacidade de reformulação das metas). ${ }^{34}$ Características estas que devem estar presentes sem que isso signifique um desligamento do "modelo-base" que lhe condiciona.

As formas de prestação dos serviços públicos possuem limites não só expressos, mas implícitos, que impedem, inclusive, a alteração do regime jurídico de sua prestação. Tais limites podem ser mais ou menos abrangentes, dependendo da estabilidade institucional e mental da sociedade. Ademais, podem variar os mecanismos de sua realização em face das opções políticas legítimas de prestação direta ou indireta. Todavia, a referência inerente ao modelo constitucional institui um caráter próprio que tende a

\footnotetext{
33 BACELLAR FILHO. O poder normativo dos entes reguladores e a participação dos cidadãos nesta atividade. Serviços públicos e direitos fundamentais ..., op. cit., p. 64.

34 GABARDO. Princípio constitucional da eficiência administrativa, p. 30.
} 
permanecer no tempo como uma garantia contra qualquer tentativa de retrocesso social. No caso brasileiro, a Constituição Federal de 1988 é clara ao retratar juridicamente a imposição de um regime típico do Estado social que, por ser "parte nuclear" do sistema é emblematicamente estável. Como afirma Celso Antônio Bandeira de Mello, “os direitos sociais fazem parte do acervo histórico, jurídico, ético e cultural dos povos civilizados. Integram o patrimônio cultural do povo brasileiro". ${ }^{35}$

\section{A organização constitucional de competências para a prestação de serviços públicos entre localização e regionalização urbana}

Do ponto de vista estrito da estruturação orgânico-dogmática brasileira, nos termos em que estabelece a Constituição Federal de 1988, é preciso compreender o Estado como uma pessoa jurídica de caráter atípico. Sua personalidade jurídica é estabelecida artificialmente em nível constitucional, reconhecendo a primazia da sua natureza pública (embora admita exceções, as pessoas estatais de direito privado - o que não deixa de ser algo curioso). De todo modo, ser uma pessoa essencialmente de Direito Público significa que sua organização e relacionamento com terceiros são regidos por normas de idêntica natureza, seja nas suas relações externas (fruto do exercício horizontal da soberania) ou do espaço interno (resultado do exercício vertical da soberania).

Ocorre que a República Federativa do Brasil, em que pese o reconhecimento de sua existência político-jurídica como "pessoa", não exerce "pessoalmente" sua personalidade. Por razões de eficiência administrativa e também como decorrência de um processo histórico de consolidação do sistema federativo, ${ }^{36}$ o Brasil encontra-se primeiro dividido em pessoas políticas (União, Estados, Distrito Federal e Municípios) e, depois, em pessoas administrativas (Autarquias, Fundações Públicas, Empresas Públicas e Sociedades de Economia Mista). Todas elas dotadas de autoadministração, ainda que as primeiras possam inovar no sistema jurídico, mediante a edição de leis e as segundas não possuam esta prerrogativa, haja vista que estão vinculadas pelo princípio da legalidade estrita.

Há, portanto, várias formas de descentralização que foram sendo constituídas historicamente, seja ela política, seja meramente administrativa.

\footnotetext{
${ }^{35}$ MELLO. Eficácia das normas constitucionais e direitos sociais, p. 57.

${ }^{36}$ Resultado de um longo debate que foi típico da história política do Brasil. Sobre o assunto, ver: FERREIRA. Centralização e descentralização no império.
} 
Aliás, este fenômeno é típico do incremento da complexidade social e das exigências em face do Estado que não pararam de ser ampliadas a partir da superação do Estado liberal. Maria Sylvia Zanella di Pietro aponta pelo menos três maneiras fundamentais de ser efetuado o repasse de atividades públicas para escalões de caráter inferior: a geográfica ou territorial, a por serviços ou funcional e a por colaboração. Todas elas possuem relevância quando referido o processo de identificação do titular e do prestador dos serviços públicos. Por um lado, concretizando um ideal de especialização e, por outro, utilizando métodos de gestão privada, o Poder Público desenvolveu meios de repasse de suas atividades com vista à obtenção de resultados mais eficientes. ${ }^{37}$ A concessão e a permissão de serviços públicos são exemplos profícuos desta realidade (que não é nova, mas que evolui de forma pendular, de acordo com as opções político-interventivas do Estado).

A Constituição não traz uma real definição de serviço público, restringindo-se apenas em elencá-los e atribuí-los. No máximo, resta no artigo 175 a consagração da possibilidade de prestação "direta ou indireta", sendo que, em qualquer caso, trata-se de um "dever" do Estado. Daí que, para conhecer a divisão orgânica de titularidade da prestação dos serviços públicos (e aqui já não se está tratando mais dos chamados serviços sociais) basta recorrer aos artigos que tratam da competência dos entes federativos.

Preliminarmente, cumpre destacar que a existência de competências específicas previamente delimitadas para a titularidade dos serviços não resolve o problema da interconexão de matérias. Deve-se observar que a doutrina, de muito, consagrou a diferença entre as competências exclusivas (atribuídas a um ente com exclusão dos demais, pelo que, indelegável), privativas (próprias de uma entidade, mas passível de transferência e suplementação; delegável, portanto), concorrentes (cujas normas gerais cabem à União, sendo possibilitada a complementação mediante normas específicas dos Estados-membros e Distrito Federal e normas suplementares dos Municípios), e, finalmente, as comuns (que pertencem a todos indiferentemente, sendo bastante variáveis conforme a matéria e situação concreta). ${ }^{38}$ Todavia, em muitas situações a estipulação formal-constitucional da competência pouco ajuda na definição de uma adequada regulação pública

\footnotetext{
37 PIETRO. Parcerias na Administração Pública: concessão, permissão, franquia, terceirização e outras formas. 4. ed., p. 51 et seq.

38 Esta, ao menos, é uma das classificações possíveis. Todavia, a falta de sistematicidade constitucional a respeito torna o assunto profícuo em controvérsias. Para mais detalhes a respeito desta classificação e de outras possíveis, ver: ALMEIDA. Competências na Constituição de 1988. 3. ed.
} 
dos setores, quando não a complica sobremaneira. Principalmente considerando-se que no Brasil já é pacífico que as normas federais, estaduais e municipais não se encontram em situação de hierarquia, sob pena de inconstitucionalidade. ${ }^{39}$

De acordo com o artigo 21 da Constituição, cabe à União Federal a realização dos serviços públicos postal e de correio aéreo nacional (inciso $\mathrm{X}$ ), telecomunicações (inciso XI), radiodifusão sonora e de sons e imagens (inciso XII, alínea “a”), instalações de energia elétrica e aproveitamento energético dos cursos de água (inciso XII, alínea “b”), navegação aérea, aeroespacial e infra-estrutura aeroportuária (inciso XII, alínea “c”), transporte ferroviário e aquaviário entre portos brasileiros e fronteiras nacionais ou que transponham os limites dos Estados (inciso XII, alínea “d”), transporte rodoviário interestadual e internacional de passageiros (inciso XII, alínea "e"). A competência para a prestação de tais serviços é estipulada em numeros clausus, pois não podem ser criados outros que não aqueles que possam ser enquadrados em um dos dispositivos retromencionados.

Aos Estados federados cabe, segundo o parágrafo primeiro do artigo 25, a prestação dos serviços de gás canalizado e, ainda, são a eles destinados todos os serviços públicos privativos do Estado não reservados à União ou aos Municípios (parágrafo primeiro do artigo 25). Isso significa que, no Brasil, os Estados são detentores de uma importante competência de caráter residual na matéria.

Finalmente, aos Municípios, que no tocante à competência políticoadministrativa são reconhecidos pelo sistema jurídico brasileiro como autênticos entes integrantes da federação, couberam os serviços intitulados genericamente como de "interesse local", de pronto exemplificados mediante a previsão específica dos serviços de transporte coletivo (dentro, obviamente, de sua jurisdição territorial).

Tradicionalmente, no Direito Comparado, o Município não faz parte da Federação. E na tradição constitucional brasileira anterior à Constituição de 1988, idem. ${ }^{40} \mathrm{Na}$ Constituição de 1891 a autonomia municipal era existente para assuntos de seu "peculiar interesse". Na de 1934 retratava matérias de caráter político, financeiro-tributário e administrativo (o que significava uma opção pelos meios descentralizantes). Já na autoritária Constituição de 1937 retorna-se ao modelo centralizado, típico de

\footnotetext{
${ }^{39}$ FERRARI. Direito municipal. 2. ed., p. 190.

40 HORTA. Direito constitucional brasileiro e as regiões metropolitanas. In: Estudos de Direito Constitucional, p. 621 et seq.
} 
um Estado com pretensões unitárias (embora preveja-se, paradoxalmente, a existência jurídica das regiões). ${ }^{41}$ Segundo Raul Machado Horta, somente com a Constituição de 1946 houve uma revigoração do Município, inclusive devido à prescrição de repasses orçamentários obrigatórios, à limitação da possibilidade de intervenção estadual e à garantia de efetiva autonomia política, reiterando-se a administração de seu "peculiar interesse", notadamente quanto aos "serviços públicos locais". E, finalmente, a Constituição de 1967 manteve o princípio da autonomia local, entretanto, ainda não incluindo o Município na distribuição de competências entre os entes federativos (sendo em 69 limitada esta autonomia, juntamente com a dos Estados, em benefício da União). ${ }^{42}$

Fato é que a identificação dos serviços de interesse local não é fácil. A imprecisão deste conceito jurídico indeterminado pode gerar interpretações ambíguas, afinal, além de existirem alterações de caráter tecnológico, sócio-econômico e institucional, "os interesses locais e regionais se cruzam e inter-relacionam". ${ }^{43}$ Por este motivo é que Rogério Gesta Leal defende a idéia de que o interesse local não surge em razão de determinadas matérias, mas em razão de situações concretas. Ou seja, embora reconheça "a existência de temas que interessam a todo o país, mas, por possuírem aspectos que exigem uma regulamentação própria para determinados locais, devem ser detalhados somente nestes locais e não em todo o território do país," o autor reconhece que "aspectos da mesma matéria podem exigir tratamentos diferenciados pela União, pelos Estados e pelos Municípios”. O fundamental, nesta perspectiva, é que não seja perdido de vista que cabe fundamentalmente ao mais próximo ente político a "formação de instrumentos normativos (bem como ações públicas conseqüentes), capazes de perseguir a efetivação da função social da cidade". ${ }^{44}$

Ocorre que esta idéia de interesse local das cidades (ainda que topicamente considerada) é confrontada com a existência cada vez mais expressiva das regiões metropolitanas (na atualidade, quando em foco os grandes centros de urbanização, em que reside a maioria da população

\footnotetext{
41 O artigo 29 da Constituição de 1937 assim previa: "Os municípios da mesma região podem agrupar-se para instalação, exploração e administração de serviços públicos comuns. O agrupamento, assim constituído, será dotado de personalidade jurídica limitada a seus fins". Por sua vez, seu parágrafo primeiro estabelecia para o Estado a competência para "regular as condições em que tais agrupamentos poderão constituir-se, bem como a forma de sua administração".

42 HORTA. Direito constitucional brasileiro ..., op. cit., p. 627- 633.

43 GROTTI. O serviço público ..., op. cit., p. 94.

44 LEAL. Direito urbanístico: condições e possibilidades da constituição do espaço urbano, p. 86 et seq.
} 
brasileira, é impossível o estudo dos serviços de transporte coletivo urbano apenas pelo viés intramunicipal). Daí a construção, desde a Emenda Constitucional no 848 à Constituição de 1967 da idéia de interesses que seriam comuns (nem gerais, nem locais). ${ }^{45}$ Os serviços de transporte (bem como o já intitulado sistema viário) na Lei Complementar no 14 de 1973 eram previstos como de caráter comum.

Por certo que os aspectos jurídicos e institucionais das regiões metropolitanas já estão estabelecidos pela Constituição de 1988. Assevera o seu artigo 25, parágrafo $3^{\circ}$, que "Os Estados poderão, mediante lei complementar, instituir regiões metropolitanas, aglomerações urbanas e microrregiões, constituídas por agrupamentos de Municípios limítrofes, para integrar a organização, o planejamento e a execução de funções públicas de interesse comum.” Desse modo, há competência estadual (e não municipal) para as questões de "interesse comum" (ou seja, metropolitano). Jurisdição esta que se aglutina à típica competência legislativa e de polícia administrativa concorrente (prevista no artigo 24 - principalmente em questões ambientais e urbanísticas).

Sendo assim, a região metropolitana deverá ser organizada pelo Estado-membro, embora com a participação dos Municípios, sem dúvida, e também não olvidando das normas gerais da União (notadamente em matéria urbanística e relativa ao meio ambiente, como já asseverado). Veja-se que cabe a intervenção do Estado Nacional (e de todos os seus entes federativos) quando ele desempenha o papel de agente de desenvolvimento (e os serviços públicos representam fortes instrumentos de desenvolvimento, notadamente os relativos ao transporte, e mais especificamente, ao transporte coletivo). ${ }^{46}$ No mais, não é incomum as Constituições Estaduais ressaltarem o caráter plural e conexo da organização e do funcionamento das regiões metropolitanas, prevendo-se expressamente a participação

\footnotetext{
${ }^{45}$ Raul Machado Horta lembra o conceito (ainda útil) de serviços de interesse comum contido na motivação do projeto de ementa: "deixam de ser exclusivo interesse local, por vinculados estarem a toda a comunidade metropolitana. Passam a constituir a tessitura intermunicipal daquelas localidades e, por isso mesmo, devem ser planejados e executados em conjunto por uma administração unificada e autônoma, mantida por todos os municípios da região, na proporção de seus recursos, e se estes forem insuficientes, hão de ser complementados pelo Estado, e até mesmo pela União, porque os seus benefícios também se estendem aos governos estadual e federal" (cf.: HORTA. Direito constitucional brasileiro ..., op. cit., p. 647).

${ }^{46}$ A título exemplificativo, merecem menção dois artigos constitucionais paradigmáticos sobre a matéria. O artigo 174, caput, que prescreve: "Como agente normativo e regulador da atividade econômica, o Estado exercerá, na forma da lei, as funções de fiscalização, incentivo e planejamento, sendo este determinante para o setor público e indicativo para o setor privado". Já o artigo 182 estabelece: "A política de desenvolvimento urbano, executada pelo Poder Público municipal conforme diretrizes gerais fixadas em lei, tem por objetivo ordenar o pleno desenvolvimento das funções sociais da cidade e garantir o bem-estar de seus habitantes".
} 
dos Municípios e da sociedade civil. O que acaba por prestigiar a gestão associada dos serviços púbicos, conforme o disposto no artigo 241 da Constituição Federal.

\section{O caráter essencial dos serviços públicos de transporte coletivo de passageiros}

Como já asseverado, não há uma única competência para a prestação dos serviços de transporte coletivo de passageiros no Brasil. Todos os entes federativos possuem competência própria para a atividade, dependendo do seu nível de abrangência territorial. A União é responsável pelos serviços de transporte internacional e interestadual, os Estados prestam os serviços intra-estaduais e os Municípios o tipicamente urbano. Tais serviços, nos termos do artigo 175 da Constituição podem ser descentralizados mediante a utilização da "outorga" a entidade administrativa estatal ou por intermédio da delegação propriamente dita (com atribuição da execução do serviço ao particular e resguardo da titularidade ao ente político). ${ }^{47} \mathrm{Se}$ prestada diretamente, precisará de lei autorizativa de iniciativa do chefe do Poder Executivo; se indiretamente, além da respectiva lei, também de licitação promovida pela mesma autoridade.

E aqui se está tratando, obviamente, somente da competência de prestação, pois a "competência regulatória" é muito mais abrangente, podendo mesclar vários âmbitos legislativos e diversas áreas jurídicas (com clara predominância da União nesta seara, seja no tocante à regulação do trânsito, seja quando estabelece normas gerais de licitação e contratação, ou mesmo, das próprias concessões e permissões de serviço público). Do ponto de vista regulatório, o artigo 21, inciso XX, da Constituição Federal estabelece competência para a União instituir diretrizes sobre transporte urbano. Já o artigo 22, inciso XI, da Constituição Federal estabelece competência para a União Federal legislar sobre trânsito e transportes. Desse modo, os Municípios (no caso de interesse local) e os Estados (no caso de interesse comum) devem atender a normas gerais federais também relativas a estas matérias. ${ }^{48}$

Apesar das opções jurídicas pela prestação direta ou indireta dos serviços públicos, historicamente, o transporte coletivo em geral sempre foi entregue à execução da iniciativa privada no Brasil. Aliás, esta é uma

\footnotetext{
47 SOUTO. Desestatização..., op. cit., p. 310.

48 A título exemplificativo devem ser mencionadas as Leis $n^{\circ} 10.233 / 01$ e $n^{\circ} 11.518 / 07$.
} 
tendência também verificada nos ordenamentos comparados. Jean François Janin relata que a tradição de delegação dos transportes coletivos deriva de uma iniciativa do próprio setor privado. Blaise Pascal, no século XVII teria sido o primeiro que teve a idéia de colocar juntas para viajar pessoas que não se conheciam. Eram as chamadas "carrosses a cin sols". Mas é importante ressaltar que desde o início (ao menos na França) o Poder Público interveio mediante a concessão de cartas de patentes e de uma regulamentação de acesso ao serviço. ${ }^{49}$ Desse modo, ainda que atribuída a execução para os particulares, por outro lado, o tema sempre foi, e continua a ser, fortemente regulado, desde o próprio nível constitucional. Veja-e que a Constituição trata dos transportes em várias oportunidades, tais como no artigo 178, quando prevê a ordenação econômica do transporte terrestre ou no artigo 230, parágrafo $2^{\circ}$, quando confere gratuidade aos maiores de sessenta e cinco anos quando usuários de transporte coletivo urbano.

Dentro desta característica de elevada densidade regulatória, um dos pontos de relevância em relação aos transportes coletivos urbanos referese à adjetivação normativa deste serviço público como "essencial" contida no artigo 30, inciso V, da Constituição. ${ }^{50}$ Para Horácio A. Mendes de Souza "a noção de essencialidade é tão variante quanto a de serviço público". Ademais, esclarece o autor que o fato de somente o transporte coletivo ter sido elencado como essencial não significa que o interestadual, o intermunicipal e o internacional também não o sejam. ${ }^{51} \mathrm{E}$ Adilson Dallari vai além, propondo que "todo serviço público é essencial, no sentido de corresponder a uma necessidade da coletividade, como algo indispensável ao convívio, ao desenvolvimento normal das atividades dos integrantes de uma coletividade, nos dias atuais". E cita como exemplo justamente o serviço de transporte coletivo, asseverando que "pode não ser utilizado por uma parcela da população, mas ele é indispensável para o funcionamento da cidade e o Poder Público tem o dever de proporcioná-lo”. ${ }^{52}$ São procedentes as colocações dos autores, principalmente quando em foco o "princípio da continuidade dos serviços públicos”, haja vista que ao principal atributo

\footnotetext{
49 JANIN. Os sistemas de transportes coletivos. In: PERROT; CHATELUS (Org.). Financiamento das infraestruturas e dos serviços coletivos: o recurso à parceria púbico-privado. Os exemplos da experiência francesa no mundo, p. 185.

50 "Art. 30. Compete aos Municípios: (...) V - organizar e prestar, diretamente ou sob regime de concessão ou permissão, os serviços públicos de interesse local, incluído o de transporte coletivo, que tem caráter essencial."

51 SOUZA. Regulação jurídica do transporte rodoviário de passageiros, p. 46-47.

52 DALLARI. Tarifa remuneratória dos serviços concedidos. In: TÔRRES (Coord.). Serviços públicos e direito tributário, op. cit., p. 216.
} 
da essencialidade são as garantias e restrições em face da possibilidade de paralisação. Ou seja, para alguns intérpretes, todos os serviços públicos são essenciais, pela sua própria natureza de satisfação de uma necessidade de atendimento perene. Nesse sentido ponderam, por exemplo, Ana Maria Golffi e Flaquer Scartezzini, quando afirmam: "como o serviço público antes de um conceito jurídico é um fato, uma de suas características essenciais é a continuidade, que está ligada é eficiência da prestação, pois só assim será oportuna. A sua prestação não deve ser interrompida, sob pena de prejudicar justamente o beneficiário, o destinatário para o qual o serviço foi criado." ${ }^{53}$

Finalmente, o parágrafo $1^{\circ}$ do artigo $9^{\circ}$ da Constituição Federal prescreve que "a lei definirá os serviços ou atividades essenciais e disporá sobre o atendimento das necessidades inadiáveis da comunidade." Sendo assim, parece razoável supor que a vinculação dos transportes coletivos como essenciais é meramente exemplificativa, podendo o legislador infraconstitucional ampliar os casos. Neste sentido, segue a regra do artigo 22 do Código de Defesa do Consumidor, que estabelece: "os órgãos públicos, por si ou suas empresas, concessionárias, permissionárias ou sob qualquer outra forma de empreendimento, são obrigados a fornecer serviços adequados, eficientes, seguros e, quanto aos essenciais, contínuos". Norma esta que deve ser interpretada de acordo com o elenco dos serviços essenciais (que não sejam necessariamente os tidos como públicos) da Lei $n^{\circ} 7.783 /$ 89, que assim os identifica, em cada um dos incisos do seu artigo 10: "I tratamento e abastecimento de água; produção e distribuição de energia elétrica, gás e combustíveis; II - assistência médica e hospitalar; III distribuição e comercialização de medicamentos e alimentos; IV - funerários; V - transporte coletivo; VI - captação e tratamento de esgoto e lixo; VII telecomunicações; VIII - guarda, uso e controle de substâncias radioativas, equipamentos e materiais nucleares; IX - processamento de dados ligados a serviços essenciais; X - controle de tráfego aéreo; XI - compensação bancária”. Vê-se, pois, que este rol contempla atividades econômicas em sentido estrito, ao lado de alguns serviços públicos (não todos). Destarte, em alguns casos, reporta-se a expressões genéricas, que não traduzem diretamente o serviço em questão (caso das telecomunicações). Razão pela qual, a questão não pode ser definida apenas pelo texto formal da lei em sentido

53 GOLFFI; SCARTEZZINI. O princípio da continuidade do serviço público, p. 94. 
estrito, mas sim do ordenamento como um todo e da sua interpretação sistemática, notadamente mediante a imposição dos princípios como condicionantes do regime jurídico aplicável.

E, como já asseverado, o princípio da continuidade é um dos princípios de maior destaque nesta questão, impondo a todos os serviços públicos, inclusive aqueles objetos de concessão, alguns condicionamentos. E isso tem especial relevo quando os serviços são concedidos ou permitidos, como é o caso do transporte coletivo, pois dele decorrem prerrogativas para a Administração, tais como a capacidade de intervenção na empresa delegatária no caso de inadequação na execução, a imposição de prazos de modernização, e o poder de utilização de equipamentos e também pessoal da empresa, em casos excepcionais, garantindo assim a regularidade. ${ }^{54}$ Desse modo, as empresas não têm o direito de cessar a prestação, mesmo em situações nas quais, normalmente teriam (como nos contratos de direito privado), permissão legal para a recusa da sua contrapartida obrigacional. Ou seja, resta afastada a exceptio non adimplenti contractus. Obviamente que esta regra não é absoluta. Como explica Marçal Justen Filho, em caso de ser caracterizada uma "situação de sacrifício acima do razoável, é perfeitamente admissível a suspensão da atividade". Contudo, em geral, aplicase a possibilidade apenas de suspensão do serviço nos termos do artigo $6^{\circ}$, parágrafo $2^{\circ}$, da Lei n ${ }^{\circ}$ 8.987/95: motivos de ordem técnica ou de segurança e o inadimplemento do usuário. Sendo o segundo caso interpretado de forma relativa, pois, conforme aduz o autor, esta hipótese legal não autoriza "a suspensão dos serviços obrigatórios, cuja prestação se faz no interesse público ou é essencial à dignidade da pessoa humana (normalmente serviços ligados à saúde pública)" ${ }^{55}$

E aqui é que a questão torna-se bastante difícil de ser compreendida. Afinal, se a essencialidade é ligada à dignidade, implicando a impossibilidade de cessação da disponibilização ao usuário, como fica então o caso dos transportes coletivos, cujas empresas embora tratando também de atividade constitucional e legalmente essencial, somente prestam-na aqueles que efetivamente pagam a tarifa (com as devidas exceções do ordenamento). Em que termos pode ser essencial uma atividade que, por definição, é negada a quem não pode efetuar o respectivo pagamento? Parece que, implicitamente, o sistema jurídico brasileiro faz uma distinção entre os serviços

\footnotetext{
${ }^{54}$ GOLFFI; SCARTEZZINI. O princípio da continuidade ..., op. cit., p. 99.

55 JUSTEN FILHO. Teoria geral das concessões ..., op. cit., p. 309-310.
} 
cuja essencialidade é de caráter singular e aqueles em que o caráter essencial ocorre justamente pelo seu caráter coletivo. Ou seja, a priori, do ponto de vista formal nossos legisladores (bem como a doutrina e a jurisprudência pátrias) não parecem considerar uma afronta à dignidade humana a recusa individualizada de prestação dos serviços, mas sim sua paralisação completa, cujo prejuízo acaba sendo suportado por toda a sociedade, gerando um problema social de grandes proporções. Daí o foco da aplicação da essencialidade residir no controle da atuação das empresas e na limitação do direito de greve, quando em relevo o transporte coletivo.

\section{Os serviços públicos de transporte coletivo rodoviário em face do meio ambiente urbano}

Costuma-se a identificar a década de 1920 como a inicial em termos de transporte rodoviário no Brasil, especialmente em face da construção da Rodovia Rio-São Paulo (única pavimentada até 1940). ${ }^{56}$ Foi com o colapso do modelo econômico até então vigente na década de 1930 que se propiciou, no Brasil, o retorno da tendência de centralização das atividades administrativas. Tal fato, por sua vez, fomentou a implantação de uma infra-estrutura rodoviária, principalmente no período posterior à Segunda Guerra. De maneira sem precedentes na história nacional, são ampliados os investimentos não somente nas rodovias, como também em ferrovias, portos, energia e telecomunicações (por meio de empresas estatais que substituem, paulatinamente, as empresas privadas então concessionárias dos serviços). A forte liderança da União Federal no período de industrialização intensa ocorrido das décadas de 1930 a 1980 propiciou a unificação do mercado interno e, finalmente, o desenvolvimento industrial que incrementou a urbanização e o desenvolvimento (como todas as externalidades decorrentes deste processo - em geral não planejado). ${ }^{57}$

A partir da década de 1980 os problemas inerentes à mobilidade urbana, em relação à qual o transporte coletivo rodoviário é atividade essencial à qualidade de vida geral da sociedade, somente se agravaram. A incrementação da densidade populacional sobrecarrega cada vez mais o serviço de transporte, cujas dificuldades decorrem também da ausência de políticas públicas adequadas, do aumento do transporte individual, da

\footnotetext{
56 RODRIGUES. Introdução aos sistemas de transportes no Brasil e à logística internacional. 4. ed., p. 47.

57 BARAT. Logística, transporte e desenvolvimento econômico: a visão institucional, v. 2, p. 7 et seq.
} 
precariedade do sistema fiscalizatório e do recorrente péssimo planejamento urbano das cidades e da malha viária do país. ${ }^{58} \mathrm{O}$ governo passa a fomentar de maneira intensa o transporte de passageiros interestadual e internacional por vias exclusivamente rodoviárias, esquecendo-se da ausência de condições financeiras adequadas à sua manutenção e, também, de que este meio consistente no transporte rodoviário é indicado para as transferências em pequenas distâncias, ou seja, que não ultrapassem o raio de $500 \mathrm{~km}$. Acima disso, afeta-se progressivamente a economicidade, pelo elevado consumo energético verificado. Conforme esclarece Paulo Roberto Rodrigues, baseado em dados da Associação Brasileira de Logística, "por sua elevada flexibilidade, este modal (o rodoviário) é indicado para a distribuição urbana, cujas transferências são de pequenas distâncias, além das inevitáveis conexões com os demais modais". ${ }^{59}$

Neste fim da primeira década do século XXI, as cidades têm sido acometidas de uma série de situações adversas, como a degradação das condições ambientais, a convivência com congestionamentos crônicos, os altos índices de acidentes e, paradoxalmente, a ausência de mecanismos institucionais adequados que possibilitem o uso racional dos espaços urbanos. Resta claro o prestígio que o automóvel possui em termos de fomento estatal (vejam-se as comuns isenções tributárias concedidas como meio de fomento econômico). Para as forças especulativas do mercado, a produção de combustíveis, de automóveis, de peças, acessórios e pneus têm sido uma fonte lucrativa de recursos, ocasionando a redução das calçadas e das áreas verdes, o aumento dos espaços necessários ao estacionamento e a transformação das praças em rotatórias, além de outras externalidades negativas. ${ }^{60}$

Um dos mais relevantes efeitos adversos do prestígio do transporte individual em detrimento do coletivo nas cidades brasileiras é justamente o ambiental. Os efeitos do transporte automotor na qualidade do ar têm sido devastadores no mundo todo, o que implicou a criação de formas de controle que vão da imposição de limitações para a emissão de gases (especificamente impostas aos fabricantes) à cobrança pelo direito de circular (road pricing). ${ }^{61}$ Os automóveis são os principais emissores de monóxido de carbono,

\footnotetext{
58 COSTA. O princípio da eficiência e a competitividade nos serviços públicos de transporte coletivo. In: SOUTO; MARSCHALL. Direito empresarial público, p. 559.

${ }^{59}$ RODRIGUES. Introdução aos sistemas de transportes ..., op. cit., p. 49.

${ }^{60}$ LIMA. A crise do transporte urbano: o que o governo federal tem a ver com isso. Revista dos Transportes Públicos, ano 21, n. 81, p. 31 et seq.

${ }^{61}$ VASCONCELLOS. Transporte urbano nos países em desenvolvimento: reflexões e propostas. 3. ed., p. 37.
} 
hidrocarbonetos e óxidos de nitrogênio, numa proporção por volume anual em toneladas de $97,8 \%$ para CO, $96,1 \%$ para $\mathrm{HC}$, e $67,4 \%$ para NOx (enquanto os ônibus emitem 2\%, 3,4\% e 28,5\%, respectivamente). A título comparativo é interessante observar que em um trecho de $7 \mathrm{~km}$ no eixo Rebouças/Consolação, na cidade de São Paulo, $94 \%$ dos veículos circulantes são automóveis, que respondem por $44 \%$ dos passageiros e $5 \%$ são ônibus, que respondem por $55 \%$ dos passageiros. Ou seja, o transporte coletivo polui por passageiro muitíssimo menos que os automóveis. ${ }^{62}$ Ademais, a acessibilidade está distribuída de forma desigual. Asseverar que a utilização de determinado modal de transporte é uma opção do indivíduo que poderia escolher entre o transporte público ou o privado é uma visão simplista do fenômeno urbano que Eduardo Vasconcelos denomina de "iniqüidade de acessibilidade", cujo conteúdo compreende as relações não isonômicas em termos de tempo de acesso, velocidade, conforto, uso do espaço, segurança e proteção ambiental. ${ }^{63}$

Caminhando em sentido contrário ao da globalização dos problemas locais, cada vez mais a União e os Estado parecem querer eximir-se da questão (no máximo, legislando genericamente sobre matérias pelas quais a Constituição lhes reputa responsáveis, mas sem a preocupação direta com o problema). Obviamente, é difícil imaginar qual seria a solução para os problemas atualmente vivenciados, mas parece condição imprescindível à sua resolução que as três esferas da federação responsabilizem-se por medidas tanto preventivas e compensatórias. Não é possível mais imaginar que se trata de problemas exclusivamente locais ou mesmo regionais, sob o controle apenas do Município ou do Estado. Afinal, a competência geral para a proteção do meio ambiente é das três esferas da federação, mesmo que algumas atividades sejam realizadas em um ecossistema urbano localizado. Entretanto, na prática, ainda pode ser verificada uma série de conflitos e ausências institucionais. Em nível federal, devido à dificuldade de coordenação entre as diferentes instâncias competentes: transportes, minas e energia, ciência e tecnologia, fazenda e meio ambiente. Já no nível estadual são reproduzidos vários dos conflitos federais, ainda que em menor grau, mas seu maior problema tem sido encontrar os meios mais adequados para a gestão das regiões metropolitanas, cujas disputas de poder político, incrementadas pelo confronto entre o interesse público e os interesses

62 VASCONCELLOS. Transporte urbano nos países ..., op. cit., p. 41.

63 VASCONCELLOS. Transporte urbano nos países ..., op. cit., p. 43. 
econômicos privados reduzem a possibilidade de uma solução realmente consensual e eficiente. E, finalmente, na esfera municipal, a precariedade das suas disponibilidades orçamentárias, somada à falta de adesão ao Sistema Nacional de Trânsito e à ausência de políticas locais de urbanismo e transporte, torna crônica a dificuldade de construção de um meio ambiente urbano equilibrado. ${ }^{64}$

A solução para os problemas concernentes ao serviço público de transporte (e inerentes à mobilidade no ambiente urbano em geral) parece residir no desenvolvimento de um sistema interfederativo que permita resultados com eficiência, segurança e acessibilidade aos usuários, sem deixar de ser atrativo para as empresas delegatárias. Neste contexto, o poder concedente deve estipular critérios e modos de prestação visando: a ampliação progressiva da qualidade dos serviços, a preocupação com a criação de empregos, a adequação entre a ampliação dos usuários e o consumo dos combustíveis, a justiça social com isonomia de atendimento, a estipulação de metas, objetivos e condições claras e seguras, pautadas pela confiança entre contratante e contratados. ${ }^{65}$ Conforme define Paolo Henrique S. da Costa: "a eficiência da prestação de serviços públicos decorre da qualidade da execução dos serviços outorgados à concessionária no cumprimento das metas estabelecidas no contrato de concessão, que, a rigor, deve refletir o interesse da coletividade naquela determinada época, e com o nível de tecnologia permitido e conhecido" ${ }^{66}$ Este raciocínio leva à conclusão de que a comum delegação dos serviços de transporte coletivo por intermédio do instituto da permissão também consiste em um sério problema. Obviamente a atividade de transporte, pela sua própria natureza, não admite ser pactuada por meio da permissão. Trata-se de um caso típico a ser regido pela concessão. Mas não é isso que em geral ocorreu no Brasil, cuja Administração Pública demorou muito para verificar que, para ambas as partes, é imprescindível a proteção típica do contrato. Como bem coloca Romeu Felipe Bacellar Filho, a permissão, quando firmada a termo e em condições de bilateralidade, não admite a precariedade nem a revogabilidade trata-se, pois, de um efetivo contrato. Desse modo, e mediante a incidência recíproca dos deveres de coerência, lealdade e transparência, torna-se segura a relação entre a Administração e o parceiro particular, além de

\footnotetext{
${ }^{64}$ Sobre o assunto ver: VASCONCELLOS. Desvendando a política brasileira da mobilidade urbana. Revista dos Transportes Públicos, ano 28, n. 108, p. 15.

${ }^{65}$ COSTA. O princípio da eficiência ..., op. cit., p. 560 et seq.

${ }^{66}$ COSTA. O princípio da eficiência ..., op. cit., p. 572.
} 
mais promissora a realização eficiente do serviço. ${ }^{67}$ Embora os serviços de transporte rodoviário em geral sejam atribuídos a um único concessionário, a busca de competitividade no setor tem levado o Poder Público a constituir situações de "transporte multimodal". Nestes casos, se a Administração baixa a tarifa do ônibus, isso afeta a barca que perde clientes. Ou então, se o serviço de transporte por veículo metropolitano (metrô) é subsidiado diretamente e não o rodoviário, este perde competitividade. As variáveis destes casos precisam ser analisadas com cautela, embora a jurisprudência tenha sido bastante simplista, atribuindo apenas às concessionárias o ônus de tal atividade administrativa, que Paolo Costa entende consistir em autêntico "fato do príncipe", o que implicaria um reequilíbrio dos contratos cujos concessionários foram prejudicados. ${ }^{68}$ Parece ser um caso autêntico de deslealdade quando a Administração pretende, após firmado o contrato, alterar as condições inerentes ao sistema (ainda que não especificamente ao modal rodoviário) sem se preocupar com o equilíbrio econômico-financeiro da relação pactuada em condições pretéritas diversas.

Mas a questão não se restringe aos vínculos contratuais específicos de cada caso. As delegações de serviço público devem ser acompanhadas de políticas públicas, especialmente de financiamento, que fomentem os transportes públicos (e não o inverso, que tem sido o comumente observado, como no caso da recente redução do Imposto sobre Produtos Industrializados dos automóveis). A implantação de subsídios para a redução do valor da tarifa seria uma destas medidas. Além, é claro, de outras relativas ao urbanismo e ao meio ambiente (que certamente ultrapassam as fronteiras intramunicipais). Conforme lembra Iêda de Oliveira Lima, muitas vezes as autoridades administrativas esquecem que as externalidades negativas típicas da ausência dos mecanismos institucionais adequados acabam tendo forte impacto no valor da tarifa (algo em torno de 10\% nos grandes centros). Veja-se que a área ocupada por quem é transportado por automóvel é muito maior do que aquela ocupada por quem transita em ônibus (em São Paulo, quase 15 vezes mais espaço). ${ }^{69}$

Daí a necessidade de normas de intervenção do Estado que compreendam três planos estruturantes: o planejamento urbano (que define como

\footnotetext{
67 BACELLAR FILHO. As concessões, permissões e autorizações de serviço público, op. cit., p. 416 et seq.

68 COSTA. O princípio da eficiência ..., op. cit., p. 585.

69 LIMA. A crise do transporte urbano: o que o governo federal tem a ver com isso. Revista dos Transportes Públicos, op. cit., p. 35.
} 
os locais urbanos devem ser ocupados, além de delimitar uso da propriedade privada nestes espaços), o planejamento de circulação (que implica o estabelecimento de regras de trânsito e de tráfego, além de fiscalização e até mesmo educação social), e, finalmente, o planejamento de transportes (que regula a infra-estrutura de circulação de mercadorias e pessoas, tamanho das ruas e calçadas, vias férreas, terminais, estrutura das linhas de transporte público, freqüência das viagens, etc). ${ }^{70} \mathrm{~A}$ intenção destes instrumentos deve ser a de reduzir os elementos de piora progressiva das condições de prestação do serviço, tais como: a dificuldade de financiamento, o crescimento do transporte informal (kombis, vans, taxis-lotação, microônibus), a queda de produtividade das empresas de transporte por ônibus (principalmente após a década de 90), a precariedade da fiscalização de trânsito e transporte em geral, e a evolução desequilibrada das tarifas em face dos custos operacionais. Custos estes que são suportados especialmente pelos usuários de baixa renda (clientes cativos do sistema público). ${ }^{71}$

A intervenção do Estado nesta realidade é indiscutível, seja mediante instrumentos de regulação e fiscalização, seja por meio direto de ampliação dos investimentos (o que pode ser realizado em parceria com a iniciativa privada). Nesse sentido, o governo federal deve procurar resistir ao "loby conservador" que insiste na descentralização respaldada pelo malfadado princípio da subsidiariedade como meio de desresponsabilização e omissão da União Federal (que tem se recusado a ampliar os recursos para investimentos no transporte urbano). Deve-se ressaltar que nos últimos anos, com a forte redução do déficit público no país, tem ocorrido muitos investimentos diretos para outras espécies de serviços públicos concedidos, tais como os da área de saneamento. Ou mesmo, há fartos recursos para setores como o da habitação (que é uma atividade econômica em sentido estrito). Todavia, quando pensado o transporte coletivo, permanece forte resistência em relação à utilização mecanismos de compensação que não os financiados exclusivamente pela própria tarifa. ${ }^{72}$ Em geral, os empresários do setor são sempre considerados os culpados pela elevação das tarifas perante a comunidade, pois isso é confortável aos agentes políticos, que se exoneram da responsabilidade sempre que a medida é impopular. Esta atitude em regra desleal com o setor privado desfavorece a existência de

\footnotetext{
70 VASCONCELLOS. Transporte urbano nos países ..., op. cit., p. 49.

71 LIMA. A crise do transporte urbano ..., op. cit., p. 37.

72 LIMA. A crise do transporte urbano ..., op. cit., p. 38.
} 
uma real competição no setor, por meio da redução dos interessados em desenvolver tal atividade econômica.

Ignora-se, assim, que os transportes retratam um locus sócio-ambiental em que a parceria com os agentes privados pode trazer grandes benefícios para a eficácia e a qualidade no serviço (sempre mantendo-se a tradição de uma forte regulação em benefício dos usuários). Defendendo esta proposição, Jean François Janin ressalta que por intermédio de uma política público-privada bem conduzida torna-se possível não somente contornar as conseqüências negativas da atividade de transporte, como produzir externalidades efetivamente positivas, como, por exemplo, consolidandose na prática o conceito de "mobilidade durável". Contudo, o êxito destes serviços em parceria depende de uma "boa regulação das necessidades de serviços públicos", além de uma "fiscalização de qualidade", inclusive, se necessário, com o Poder Público participando do financiamento das infra-estruturas a fim de permitir às empresas a rentabilidade necessária. ${ }^{73}$ Ademais, conforme sustenta Iêda M. de Oliveira Lima, a participação ativa do governo federal na busca tanto por empréstimos externos quanto por investimentos diretos, "na composição de fontes de financiamento e criação de programas estruturadores para o setor, incluindo a modernização tecnológica, a melhoria da qualidade e da produtividade dos serviços e a reorganização das funções do setor público e da iniciativa privada na prestação dos serviços de transporte público urbano, se faz tão necessária quanto nos setores da saúde, educação, saneamento e habitação". ${ }^{74} \mathrm{O}$ que não torna menos importante a atuação dos Estados e Municípios na concretização dos serviços públicos, nos termos dos princípios estabelecidos constitucionalmente, tais como o da proteção ao meio ambiente e o da dignidade humana.

Segundo Marcos Juruena V. Souto, tal atividade regulatória, para que seja realizada de forma ótima, deverá propor regras objetivas sobre os meios adequados, a eliminação da concorrência desleal modal, a coordenação e o planejamento, a eficiência na prestação, a preocupação com os portadores de deficiência, a fiscalização pelo Poder Público, a atenção ao usuário, a realização de cálculos tarifários e o respectivo controle das tarifas, além da promoção da segurança (mediante, por exemplo, a verificação perene da atualidade da frota). ${ }^{75} \mathrm{Um}$ modelo institucional ótimo

\footnotetext{
73 JANIN. Os sistemas de transportes coletivos, op. cit., p. 185 et seq.

74 LIMA. A crise do transporte urbano ..., op. cit., p. 38.

75 SOUTO. Desestatização..., op. cit., p. 305.
} 
de regulação jurídica das atividades de transporte urbano a partir da consideração de sua potencial aglutinação metropolitana certamente que implicará a existência de uma interação construtiva entre os diferentes agentes públicos e privados (o que não é tarefa fácil), bem como exige a atuação governamental prioritariamente preventiva a fim de garantir a qualidade de vida dos indivíduos. Assuntos em geral dissociados, o desenvolvimento social, a habitação, a defesa do meio ambiente, devem ser relevados no planejamento do transporte coletivo em geral e no rodoviário especificamente (pois é o modal mais importante e de maior impacto nas condições de vida das pessoas).

Todos estes indicativos que precisam ser considerados pelos Poderes Públicos implicam, a identificação de cinco orientações fundamentais para o transporte coletivo urbano contidas no ordenamento positivo brasileiro: prioridade ao transporte público, limitação do acesso e uso do automóvel nos centros urbanos, privilégio de acesso a ciclistas e pedestres, gestão unificada do transporte entre as entidades federativas, e co-participação entre o setor público e privado na execução de tais serviços públicos. ${ }^{76}$

\title{
Competency to Provide Public Services and the Collective Road Transportation in the Urban Environment
}

\begin{abstract}
The article contemplates the Public Services of collective road transportation in Brazil. It begins describing the general regime of the Public Services as specie of economic activity lato sensu. It states the juridical regime from the constitutional idea of a Welfare and Interventor State model. It also contemplates the constitutional organization of competencies for providing Public Services focusing on the question of the federative location and the urban regionalization. The essential character of the collective transportation of passengers is also referred to. Finally it emphasizes the relation between the collective road transportation services and the urban environment.
\end{abstract}

Key words: Public services. Collective transportation. Environment.

\section{Referências}

ALMEIDA, Fernanda Dias Menezes de. Competências na Constituição de 1988. 3. ed. São Paulo: Atlas, 2005.

BACELLAR FILHO, Romeu Felipe (Coord.). Direito administrativo contemporâneo. Belo Horizonte: Fórum, 2004.

${ }^{76}$ LIMA. A crise do transporte urbano ..., op. cit., p. 40. 
BACELLAR FILHO, Romeu Felipe. As concessões, permissões e autorizações de serviço público. In: CARDOSO, José Eduardo Martins et al. (Org.). Curso de direito administrativo econômico. São Paulo: Malheiros, 2006.

BACELLAR FILHO, Romeu Felipe. Direito administrativo. 4. ed. São Paulo: Saraiva, 2008.

BACELLAR FILHO, Romeu Felipe. O poder normativo dos entes reguladores e a participação dos cidadãos nesta atividade. Serviços públicos e direitos fundamentais: os desafios da regulação na experiência brasileira. AeDP - Actualidad em el Derecho Público, Buenos Aires, n. 18/20, 2002.

BARAT, Josef. Logística, transporte e desenvolvimento econômico: a visão institucional. São Paulo: Cla, 2007. v. 2.

CORTES, Alberto Baltra. Teoria económica. Santiago do Chile: Andres Nello, 1968.

COSTA, Paolo Henrique Spilotros. O princípio da eficiência e a competitividade nos serviços públicos de transporte coletivo. In: SOUTO, Marcos Juruena Villela; MARSCHALL, Carla C. Direito empresarial público. Rio de Janeiro: Lumen Juris, 2002.

DALLARI, Adilson Abreu. Tarifa remuneratória dos serviços concedidos. In: TÔRRES, Heleno Taveira (Coord.). Serviços públicos e direito tributário. Rio de Janeiro: Lumen Juris, 2005.

FERRARI, Regina Maria Macedo Nery. Direito municipal. 2. ed. São Paulo: Revista dos Tribunais, 2005.

FERREIRA, Gabriela Nunes. Centralização e descentralização no império. São Paulo: Ed. 34, 1999.

GABARDO, Emerson. Eficiência e legitimidade do Estado. São Paulo: Manole, 2003.

GABARDO, Emerson. Interesse público e subsidiariedade: o Estado e a sociedade civil para além do bem e do mal. Belo Horizonte: Fórum, 2009.

GABARDO, Emerson. Princípio constitucional da eficiência administrativa. São Paulo: Dialética, 2002.

GASTALDI, José Petrelli. Elementos de economia política. 17. ed. São Paulo: Saraiva, 1999.

GOLFFI, Ana Maria; SCARTEZZINI, Flaquer. O princípio da continuidade do serviço público. São Paulo: Malheiros, 2006.

GROTTI, Dinorá Adelaide Musetti. O serviço público e a Constituição de 1988. São Paulo: Malheiros, 2003.

HORTA, Raul Machado. Direito constitucional brasileiro e as regiões metropolitanas. In: Estudos de Direito Constitucional. Belo Horizonte: Del Rey, 1995.

JANIN, Jean François. Os sistemas de transportes coletivos. In: PERROT, Jean-Yves; CHATELUS, Gautier (Org.). Financiamento das infraestruturas e dos serviços coletivos: o recurso à parceria público-privado. Os exemplos da experiência francesa no mundo. Tradução de Nádia Dalla Déa. Paris: Ministère de l'equipement, des transports et du logement Direction des affaires économiques et internationals, [199?].

JUSTEN FILHO, Marçal. O direito das agências reguladoras independentes. São Paulo: Dialética, 2002.

JUSTEN FILHO, Marçal. Teoria geral das concessões de serviço público. São Paulo: Dialética, 2003.

A\&C R. de Dir. Administrativo \& Constitucional, Belo Horizonte, ano 9, n. 37, p. 143-174, jul./set. 2009 
JUSTEN, Monica Spezia. A noção de serviço público no direito europeu. São Paulo: Dialética, 2003.

LEAL, Rogério Gesta. Direito urbanístico: condições e possibilidades da constituição do espaço urbano. Rio de Janeiro: Renovar, 2003.

LIMA, Iêda Maria de Olivera. A crise do transporte urbano: o que o governo federal tem a ver com isso. Revista dos Transportes Públicos, São Paulo, ano 21, n. 81, 1998.

MEDAUAR, Odete. Ainda existe serviço público?. In: TÔRRES, Heleno Taveira (Coord.). Serviços públicos e direito tributário. Rio de Janeiro: Quartier Latin, 2005.

MELLO, Celso Antônio Bandeira de. Eficácia das normas constitucionais e direitos sociais. São Paulo: Malheiros, 2009.

MONCADA, Luis Cabral de. A subsidiariedade nas relações do Estado com a economia e a revisão constitucional. In: MIRANDA, Jorge (Coord.). Estudos em homenagem ao prof. Doutor Joaquim Moreira da Silva Cunha. Lisboa: Faculdade de Direito da Universidade de Lisboa, 2005.

MOREIRA, João Batista Gomes. Direito administrativo: da rigidez autoritária à flexibilidade democrática. Belo Horizonte: Fórum, 2005.

NUSDEO, Fábio. Curso de economia: introdução ao direito econômico. São Paulo: Revista dos Tribunais, 1997.

OLIVEIRA, Fernão Justen de. Parceria público-privada: aspectos de direito público econômico. Belo Horizonte: Fórum, 2007.

OLIVEIRA, Gustavo Henrique Justino de. Contrato de gestão. São Paulo: Revista dos Tribunais, 2008.

PAREJO ALFONSO, Luciano. Eficacia y administración: três estúdios. Madrid: Instituto Nacional de Administración Pública, 1995.

PEREIRA, Cesar A. Guimarães. Usuários de serviços públicos: usuários, consumidores e os aspectos econômicos dos serviços públicos. São Paulo: Saraiva, 2006.

PIETRO, Maria Sylvia Zanella di. Parcerias na Administração Pública: concessão, permissão, franquia, terceirização e outras formas. 4. ed. São Paulo: Atlas, 2002.

RODRIGUES, Paulo Roberto Ambrósio. Introdução aos sistemas de transportes no Brasil e à logística internacional. 4. ed. São Paulo: Aduaneiras, 2008.

SOUTO, Marcos Juruena Villela. Desestatização: privatização, concessões, terceirizações e regulação. 4. ed. Rio de Janeiro: Lumen Juris, 2001.

SOUZA, Horácio Augusto Mendes de. Regulação jurídica do transporte rodoviário de passageiros. Rio de Janeiro: Lumen Juris, 2003.

TÁCITO, Caio. O retorno do pêndulo: serviço público e empresa privada: o exemplo brasileiro. In: Temas de direito público: estudos e pareceres. Rio de Janeiro: Renovar, 1997.

VALLE, Vivian Cristina Lima López. O novo conceito de serviço público. In: GUIMARÃES, Edgar (Coord.). Cenários do direito administrativo: estudos em homenagem ao professor Romeu Felipe Bacellar Filho. Belo Horizonte: Fórum, 2004.

VASCONCELLOS, Eduardo A. Desvendando a política brasileira da mobilidade urbana. Revista dos Transportes Públicos, São Paulo, ano 28, n. 108, 2005. 
VASCONCELLOS, Eduardo A. Transporte urbano nos países em desenvolvimento: reflexões e propostas. 3. ed. São Paulo: Annablume, 2000.

Informação bibliográfica deste texto, conforme a NBR 6023:2002 da Associação Brasileira de Normas Técnicas (ABNT):

GABARDO, Emerson. Competência para a prestação de serviços públicos e o transporte coletivo rodoviário no meio ambiente urbano. A\&C - Revista de Direito Administrativo \& Constitucional, Belo Horizonte, ano 9, n. 37, p. 143-174, jul./set. 2009.

Recebido em: 16.06.09

Aprovado em: 10.09.09 